\title{
FOCUS GROUP DISCUSSION AND QUANTITATIVE SENSORY ANALYSIS TO IDENTIFY SENSORY PARAMETERS OF NEW FOOD PRODUCT
}

\author{
Christianus Jodi Yonathan', Yoga Pamudya Gunawan Ristam², Vania Aurellia Wijaya ${ }^{3}$, Oki \\ Krisbianto $^{4 *}$ \\ 1,2,3,4 Food Technology Program, Faculty of Tourism, Universitas Ciputra Surabaya, Indonesia \\ ${ }^{*}$ Corresponding Author's e-mail: oki.krisbianto@ciputra.ac.id
}

\begin{abstract}
Focus Group Discussions (FGD) is a renowned method for new food product development. This research used FGD followed by Quantitative Descriptive Analysis (QDA) and Affective Test (AT) to identify the sensory parameters of pineapple wine. Based on FGD, five parameters were found to be crucial for panelists while testing the wine, i.e. distinctive pineapple aroma, sweetness, alcoholic flavor, alcoholic taste and appearance. These five parameters were then used in QDA and AT to understand the expectation of panelists on the sample which was served. It was found that FGD, QDA and AT were effective in identifying the sensory parameters of pineapple wine.
\end{abstract}

Keywords: Wine; Pineapple; Qualitative Research; Quantitative Research; Sensory

\section{INTRODUCTION}

Wine is an alcoholic drink made from grape juice or other fruits fermented using certain yeast species. The diversification of the types of fruit used as raw material for wine making causes various fruit wine products to have different and distinctive sensory characteristics even though the method and yeast starter used are the same. Making fruit wine can also be an effort to minimize post-harvest damage due to rot, for example in pineapple (Kosseva et al., 2017). Although pineapple has been used as a wine raw material for a long time, the parameters and sensory characteristics are still not clearly defined, especially among wine consumers. This study aims to identify the sensory parameters of pineapple wine which can 
then be used as a determining parameter for its quality. Qualitative and quantitative sensory analysis is used to achieve this goal.

Focus Group Discussion (FGD) is a qualitative analysis that has been used for a long time in market research for new product development, both in the food and non-food fields (Guerrero \& Xicola, 2018). As a qualitative analysis method, FGD can provide far more indepth and realistic information about respondent's attitudes and perceptions of a new product when compared to quantitative analysis (Barlagne et al., 2016; Guerrero \& Xicola, 2018). Therefore, FGD are often used as preliminary research to conceptualize relevant test parameters when quantitatively analyzing the quality dimensions of a new product (Barlagne et al., 2016).

The drawback of the FGD and other qualitative analyzes is the very strong subjectivity of the assessment and the results of the analysis that cannot be generalized to the entire population. One way to minimize this deficiency is to carry out repetition of FGD in different groups of panels (O'Sullivan, 2017). Another way that can be used is the Mixed Method, which combines qualitative and quantitative research so that the data acquired and understanding are both broad and deep (Schoonenboom \& Johnson, 2017). This study uses Quantitative Descriptive Analysis (QDA) as a follow-up test after FGD with the aim of obtaining a deep and broad understanding of the sensory parameters that need to be considered in determining the quality of pineapple wine products. In this case, The data obtained from the FGD were then used as sensory parameters for pineapple wine products through QDA testing. Schoonenboom \& Johnson (2017) said that the form of integration of the two types of analysis is one of the common ways often used in the Mixed Method, which connects the results of the analysis of a data set with the collection of the next data set.

Different from other quantitative analyzes, QDA is descriptive because the panelists also explain the characteristics of the samples they find during their testing. This method is greatly influenced by the experience and training of the panelists in conducting QDA. So far, QDA is often used to evaluate the quality level (advantages and disadvantages) of a newly developed product when compared to other similar products (Li et al., 2019). 
Panelists preference level information analyzed using the Affective Test (AT) was also carried out to complement the characteristics of pineapple wine. At the AT, panelists were asked to give subjective responses regarding their preferences for the general sensory quality of a product, such as color, aroma, texture, product taste, and so on. (Oktafa et al., 2017; Permadi et al., 2019). These three tests are used continuously to determine the sensory parameters that are important in determining the quality of pineapple wine products, as well as to determine the quality level of pineapple wine based on the assessment of panelists who are experienced and trained in determining the quality of wine.

\section{METHODS}

\subsection{Focus Group Discussion (FGD)}

The FGD was held in a discussion room that had been arranged in such a way as to support a conducive discussion process. The FGD respondents were six people who had experience drinking various types of alcoholic beverages. A total of one cup of pineapple wine sample with a volume of about $30 \mathrm{~mL}$ was presented to each respondent for evaluation and comparison with their experience in consuming wine. The discussion lasted for approximately 30 minutes and the results were used to determine the QDA and AT test parameters.

\subsection{Quantitative Descriptive Analysis (QDA) and Hedonic Test / Affective Test (AT)}

Panelists for QDA and AT were selected by a purposive sampling method through interviews to obtain eight candidates who had years of expertise and experience in consuming and tasting wine. Of the eight prospective panelists, one candidate did not pass the sensory sensitivity selection for alcohol content in the wine sample and was therefore not used. Finally, seven expert panelists were obtained to carry out the QDA and AT tests.

The test was carried out at the Sensory Laboratory of Ciputra University Surabaya with room temperature conditions of $24^{\circ} \mathrm{C}$ and bright white lights on each panelist's booth. Pineapple wine samples were assessed by the panelists based on parameters of sweetness, alcoholic taste, alcoholic flavor, pineapple flavor, and appearance. The QDA assessment was 
carried out in accordance with the method of assessment by Stone et al. (2012) followed by the AT assessment to assess the panelists preference for the parameters tested.

\section{RESULT AND DISCUSSION}

\subsection{Focus Group Discussion (FGD)}

FGD according to Stone et al (2012) is defined as a method performed to determine Affective Test, Preference Test and Acceptance Test as a whole with more varieties and descriptive results. FGD harnesses topic development of a subject by discussions to represent the product's affectivity, acceptance and preference from the consumer side.

The data collected from the FGD was recorded in the form of descriptive comparison of a parameter between two different products. Each person's image of the product is really dependent on each of their respective experiences regarding the product. However, in order to get high quality data and validity in FGD, experienced individuals of a certain related product are needed. It is also important to have those individuals to determine the aspects that affect the product (Vicsek, 2016). Therefore, it is crucial to find the right respondent correlated with the willingly discussed topic because it will considerably affect the obtained data's quality and validity.

Table 1. Pineapple Wine's Quality Parameter According to FGD

\begin{tabular}{|l|c|l|}
\hline \multicolumn{1}{|c|}{ Parameter } & Discuss Frequency & \multicolumn{1}{c|}{ Conclusion } \\
\hline Sweetness & 4 & A dominant parameter for pineapple wine's sample \\
\hline Pineapple's aroma & 3 & $\begin{array}{l}\text { Consumer expect a unique, distinctive pineapple } \\
\text { aroma }\end{array}$ \\
\hline Alcohol flavor & 2 & Affect individual's desire to drink wine \\
\hline Alcohol taste & 2 & Affect individual's desire to drink wine \\
\hline Appearance & 1 & $\begin{array}{l}\text { Clarity and color's expectation affect the class of the } \\
\text { wine }\end{array}$ \\
\hline Astringence & 1 & Not detected in pineapple wine \\
\hline Integration with food & 1 & Combination of various sensory parameters \\
\hline
\end{tabular}

There are some parameters that showed up from the previous FGD that were represented in Table 1. From the obtained data, the chosen parameters will be followed by a QDA test which include sweetness, pineapple's aroma, alcohol's taste, alcohol flavor and appearance. 
Astringence parameter was only discussed once on the FGD alongside with the discussion of sweetness parameter. A respondent stated that an experienced wine drinker will expect astringence in their drink. A product with just the right astringence is usually preferred by those individuals instead of a sweet one. Soares et al (2017) stated that astringency in grape wine is caused by the tannin compound found in grapes that mutually integrated with alcohol. These compounds were identified as polymeric procyanidins and have the ability to precipitate protein's saliva inside the mouth that further trigger astringent's taste. Tannin's content found in pineapple is $6.3 \mathrm{mg} / \mathrm{g}$ which is far lower compared to grapes at $215.84 \mathrm{mg} / \mathrm{g}$ (Nurdalilah et al, 2018; Teissedre, 2015). Because of that reason, the astringent's taste was not detected in pineapple wine and the parameter was removed from further QDA tests.

Wine integration and combination with food was also removed from the QDA parameter because of the complexity of this parameter. This parameter is a combination with other sensory parameters that requires a sensitive experienced panel that is able to detect a slight difference in flavor and has a competent sensory perception of the combination of wine and food. A respondent stated that a good wine is a wine that could be integrated with high class foods such as lobster, steak, meats and also the combination of meat and vegetables. Nevertheless, a high class wine is also expected to be able to be individually drunk without negatively influencing the drinker's mood. According to Harrington \& Seo (2015), wine and food integration need to pay close attention to some important aspects such as aroma, flavor and texture. The important things that affect those three components are acidity intensity, spiciness and sweetness of a food if juxtaposed with wine's characteristics. Wine is really not compatible if combined with a food that has too much spices because the acidity intensity of the respected food will make the wine taste bitter. For example, Kurihara (2015) did an experiment of the addition of monosodium glutamate (MSG) that could increase the level of saltiness, sourness and sweetness of a food. Wine integration with that type of food will make the astringency of the wine tastes a lot more bitter.

There was one more parameter that was not discussed entirely during FGD even though it is a crucial parameter in wine quality assessment which is acetic acid's sourness. According 
to Mylona et al (2016), acetic acid was one of the compounds generated by the microorganisms that contaminated wine, Schizosaccharomyces. However, they also stated the importance of this microbe usage to produce malolactic fermentation to reduce the malic acid content and increase the pyruvic acid and vinyl phenolic pyranol anthocyanin content that contribute to wine's flavor and naturally maintain its quality. Acetic acid level that could be tolerated in wine is not more than $1 \mathrm{~g} / \mathrm{L}$ (Mylona et al, 2016). This parameter was not used in QDA with the consideration of unique characteristics of each wine product that even though it is a significant characteristic of another wine's product it couldn't be generalized in other wines.

\subsection{Sweetness}

Sweetness was concluded to be one of the crucial parameters in pineapple wine quality's assessment. The sweetness level of wine was discussed four times during FGD and respondents agreed that sweetness should be included as an important parameter because the preference of each person's sweetness level might differ. According to the respondents, most wine connoisseurs will prefer a lower sweetness level with the combination of slight astringent for a wine. On the other hand, a higher wine sweetness level is prefered by younger generations who just enter the alcoholic beverage world. This sweetness degree became important for wine brewers for future product marketing purposes. Considering the statements above, wine brewers are able to target a specific market segment according to their respective product's characteristics. Respondents also agreed that pineapple wine products should have at least 2 types of different sweetness degrees to reach wider markets from younger generations to experts.

Respondents who assessed the pineapple wine sample said that the wine belonged to the sweet wine group because of the medium to high sweetness level. The sweetness that tasted on the end product was caused by the pineapple fruit itself and the addition of sugar in the production process. The natural sugar content in pineapple are hexose and pentose and the added sugar are sucrose and glucose. 


\subsection{Pineapple Aroma}

Aroma parameter was simultaneously defined as a unique distinctive pineapple aroma that could be smelled before the wine was drunk. This parameter is also crucial because pineapple wine as a fermented pineapple juice beverage must be able to be described its originality; just like grape wine that has to have a distinctive grape aroma as one its quality parameters. Respondents discussed pineapple wine aroma three times during the FGD session with the emphasis of consumer's preferences as a whole to the pineapple aroma of pineapple wine. It was agreed that wine's aroma has a significant effect on someone's desire to try and drink wine. If the aroma is negatively different from consumer's expectation, it will also significantly decrease their desire to buy nor consume wine product. In the discussion, respondents gave the consumer's image of a yellow wine expected to has an aroma like orange or pineapple.

Some of the researches related to the distinctive pineapple wine aroma compounds showed a result of dozens of identified volatile compound with mainly esters followed by alcohol and acids (Jiang et al, 2018; Dellacassa et al, 2017; Qi et al, 2017) Ethyl ester and fatty acid produced during the fermentation process were the most important components for fruity and creamy aroma of wine while the other important compounds that contributed for creating a distinctive aroma in pineapple wine are ethyl acetate, methyl acetate and methyl-3methylthiopropionate (Dellacassa et al, 2017; Qi et al, 2017).

\subsection{Alcohol Flavor}

Alcohol flavor in wine was included as another important parameter that concluded in FGD. Respondents described alcohol flavor as 'the kicking taste sensation' when drunk and a hot effect in the throat and body that followed afterwards. Different from aroma's perception, alcohol flavor is tightly related with the activation of tasting receptor, olfactory and chemesthetic by the alcohol compounds in the wine that enters the mouth. Receptor that was activated by the alcoholic compound will further pass the signal to the brain in the form of 
nerve stimulus that translates into alcohol flavor (Jordão et al, 2015). Therefore, alcohol flavor was classified differently from alcohol's aroma that was human's retronasal perception.

According to the respondents, alcohol flavor was related with the sweetness level of wine products. They stated that wine with higher alcohol content tend to have stronger alcohol flavor and lower sweetness level. The same statement was also given to the alcohol flavor that compliments the sweetness preference. One respondent stated that consumer's preference of alcohol flavor depends on each individual. Alcohol in pineapple wine is related with the ability of Saccharomyces cerevisiae in metabolizing sugars that are naturally contained in pineapple and added during the production process. One of the examples is the ability to generate $\beta$-fructofuranosidase, EC 3.2.1.26 to break sucrose molecules into glucose and fructose as the main nutrition for further fermentation into alcohol (Marques et al, 2016).

Fermentation was also accompanied by the formation of aliphatic and aromatic alcohol compounds further called fusel (Belda et al, 2017). In high concentration, fusel could lead to off-flavor but in the low concentration this compound along with its ester played an important role as flavor's matrix as the foundation of wine's aroma. Generated fusel compounds also depend on the type and variety of the fermented food that allow experts to assess the quality of the fermented food used in wine production through this compound (Belda et al, 2017). Therefore, this parameter also became important because it is tightly related with pineapple aroma parameters that affect one's desire to drink wine.

\subsection{Alcohol Taste}

Different from alcohol flavor, alcohol taste was defined by the respondents as bitterness tasted when the wine first entered the mouth. This parameter was set crucial in pineapple wine products because it is closely related with alcohol flavor and consumer's preference that differs per individual. Experienced wine consumers will tend to prefer stronger alcohol taste with lower sweetness level. One of the respondents described that preference as consumer's prestige, that drinking wine with stronger alcohol taste describes one's capability in physical and economical aspects. 
According to Jordao et al (2015), alcohol taste could be described as the mix of sweet, bitter, and burning sensation (oral irritation). Zhong et al (2019) also stated that the preference of bitterness and sweetness of a product that differs per individual is due to the genetic composition TAS2R38 that varies in each individual that made each person have their own preference on the 'just right' alcohol taste level. However, most wine experienced connoisseurs will tend to choose higher alcohol content wine because of their basic preference in alcoholic beverages. Fu et al (2019) also stated that genetic composition TAS2R38 is associated with alcohol consumption of the consumers that frequently drink wine and prefer a higher alcohol content. On the other hand, Jordao et al (2015) said that burning sensation was caused by the activation of TRPV1 receptors that passed to the brain. These genetic factors could be contributing to the reason why experts prefer higher bitterness and lower sweetness level of a wine.

\subsection{Appearance}

Appearance parameters include color and pineapple wine's clarity. This parameter is important because the majority of consumers will prefer a clear looking wine (very clear, tend to be transparent). One respondent argued that this factor could be proved by observing wine products in the market, most of them having clear looks. Most of the sold wines in the market have clear red looks identical with classy and elegant images. Meanwhile, murky, cloudy wine appearance is identical with lower class wine. This is due to the pineapple wine sample that has a yellow cloudy color. However, another respondent also said that wine with yellow color actually affects consumer's desire to try the wine. Spence (2016) stated that the color of a wine will affect a person's perception of taste and aroma of that wine product. Therefore, this parameter is also crucial to be further analyzed using QDA test because of its relation with consumer's expectations of wine's flavor and aroma before it is drunk.

\subsection{Quantitative Descriptive Analysis (QDA)}

Seven panelist experts who passed the selection stage were asked to carry out a QDA test based on the five sensory parameters obtained from the FGD results using standard wine 
products commonly consumed by the panelists. For instance, the appearance parameters. The maximum standard is the clearest wine product they have ever consumed, while the minimum stand is the cloudiest wine product they have ever consumed. The panelists were also asked to describe the sensory characteristics they found while testing the pineapple wine samples.

The results of the QDA test is shown on Figure 1. Based on the data, sweetness has the highest value at $76,1 \%$ and appearance has the lowest value at $23,6 \%$.

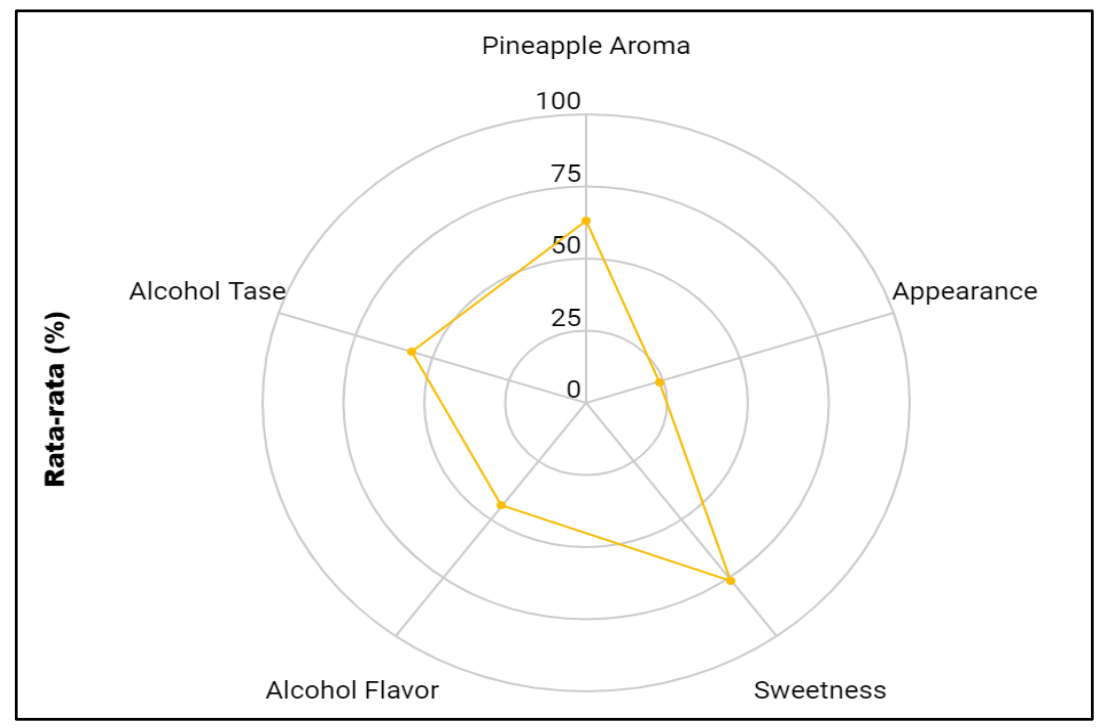

Figure 1. Spider Chart of QDA Data for Pineapple Wine Samples.

The sweetness of the pineapple wine samples may be caused by the pineapple itself and the sugar that was added during the making process. Sugar is used by added yeast to produce ethanol which can produce the taste and aroma of alcohol in wine. According to Nasrun et al (2015), the formation of alcohol in fruit juice fermentation occurs due to the overhaul of sugars such as glucose and fructose the zymase enzyme (from the invertase enzyme group) which comes from the yeast Saccharomyces sp.

As supporting data, the sugar content of pineapple wine samples is considered as total dissolved solids measured using a refractometer, which is $40^{\circ}$ Brix before fermentation and $23^{\circ}$ Brix after fermentation is stopped. Based on VinoCalc (Muster, 2018), the sugar content of pineapple wine is estimated to be a maximum of 252.19 grams per liter, provided that all 
dissolved solids are considered sucrose. This shows that most of the sugar in pineapple wine is not broken down by yeast so that the resulting sweetness is still quite high. In addition, the ethanol produced can also contribute to the sweet taste of wine (Allen et al, 2014).

The appearance parameter obtained the lowest value among the five parameters tested, which was $23.6 \%$. This shows that the pineapple wine sample has lower clarity when compared to wine products in general. One of the causes of turbidity in pineapple wine is the remains of yeast cells used for fermentation (Saputra, 2018). In addition, Jackson (2016) suggests that wines that are still young often look cloudy due to the saturated content of tartrate salts due to the fermentation process. These salts will eventually settle after the wine has aged. In addition, the pineapple wine samples also did not go through the fining process which is usually used to purify wine (Maury et al, 2019). The process of purifying pineapple wine samples itself is carried out by filtration using a filter cloth to separate the sediment from the filtrate (Farida, 2019). However, this filtering process has not been effective so that the resulting wine is less clear and there is a brownish yeast component which causes the appearance of the pineapple wine sample to become cloudy.

Among all the parameters, the aroma released by the wine is a very important parameter in measuring the quality of wine. Changes in volatile compounds during the production process to storage can change the acceptance of wine consumers towards the product (Longo et al, 2016). The distinctive aroma of pineapple in pineapple wine has a score of $63.4 \%$. This shows that the distinctive aroma of pineapple from the sample is still strong even though it is not dominant. Meanwhile, the alcoholic flavor scored lower than the distinctive aroma of pineapple, namely $44.1 \%$. Some of the panelists described the aroma that was most dominant in the sample identical to the aroma of tape. This may be caused by terpenes and ester compounds as one of the minor metabolite products of the Saccharomyces cerevisiae culture used for fermentation (Freire et al, 2015). The lack of dominance of pineapple aroma and alcohol flavor may be due to damage due to heating (pasteurization) or evaporation during storage. The decline in wine volume due to evaporation during the aging process has also long been observed by the wine industry (Longo et al, 2016; Toro et al, 2019). In the process 
of making pineapple wine samples, a high temperature heating treatment is carried out three times, allowing volatile compounds and alcohol to evaporate.

The last parameter, namely the distinctive taste of alcohol in the pineapple wine sample, had a value of $56.7 \%$. In general, fruit wine has an ethanol content of around $5.1-20 \%$, while testing the alcohol content of pineapple wine samples based on chemical analysis is $9.5 \%$, which is classified as an alcoholic drink with a low alcohol content (BSN, 2013; Qi et al., 2017).

\subsection{Hedonic Test / Affective Test (AT)}

The AT test data is shown in Figure 2. Of all the parameters tested, the alcohol taste parameter had the highest amount, namely $70.2 \%$ and the pineapple aroma parameter had the lowest value, namely $53.1 \%$. The last parameter, namely the distinctive taste of alcohol in the pineapple wine sample, had a value $56.7 \%$. In general, fruit wine has an ethanol content of around $5.1-20 \%$, while testing the alcohol content of pineapple wine samples based on chemical analysis is $9.5 \%$, which is classified as an alcoholic drink with a low alcohol content (BSN, 2013; Qi et al., 2017).

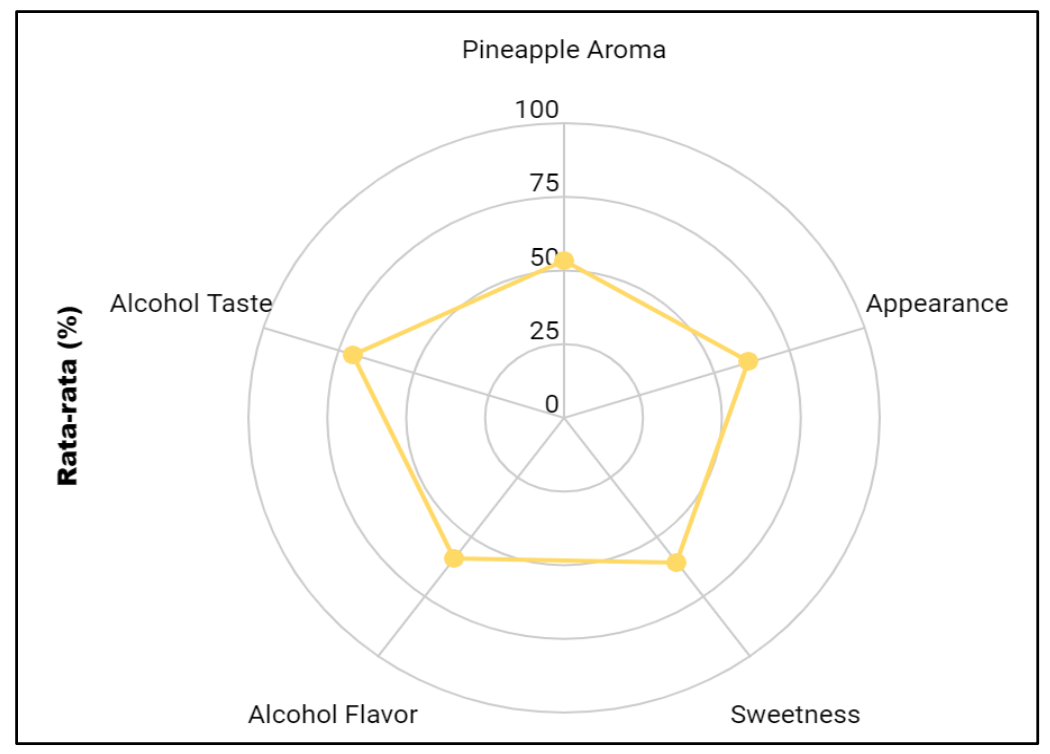

Figure 2. Spider Chart for AT Data of Pineapple Wine Sample

The taste of alcohol was the parameter of the pineapple wine sample that was most favored by the panelists with a value of $70.2 \%$. The pineapple wine sample had an alcohol 
content of $9.5 \%$. According to Allen et al (2014), there are two types of flavors that humans can feel when consuming alcohol, bitter taste and sweet taste, but the bitter taste of alcohol is more dominant than sweetness. Nanik's (2018) research results prove that the taste of fruit wine that is preferred by panelists is that which has a slightly bitter taste caused by the alcohol content. This is also related to the parameters of the sweetness of the wine, which reached $60.7 \%$. Sweet taste can reduce the perception of bitter taste by the tongue, while some panelists also argue that the pineapple wine sample does taste too sweet. Based on the results of research by Gaudette and Pickering (2013), sweetness and bitterness have the ability to mask one taste with another. Therefore, the presence of a sweet taste in food ingredients can inhibit and reduce the perception of bitter taste. However, increasing the concentration of sucrose in small amounts does not always inhibit the perception of bitter taste at low concentrations. Adding the right concentration of sugar can reduce the bitter taste. (Gaffar et al., 2018).

This also relates to the results of discussions with FGD respondents who agreed that sweet wine is more suitable for consumption by newbie consumers who are just trying wine and are not yet familiar with the bitter taste of alcoholic drinks. Generally wine producers make variations of sweet wine, or commonly known as dessert wine because it is served with dessert. Conversely, more experienced wine consumers will usually prefer wines with a low sweetness and bitterness which indicates a high alcohol content in the wine. Meanwhile, the panelists used for the AT test were panelists who were experts. This is an input for researchers to further involve common people in testing the preference for pineapple wine samples.

Based on the results of the preference test for appearance, clarity and color of the pineapple wine sample, the score was $61.5 \%$, although the clarity level was quite low based on the QDA test. Some researchers say that the level of clarity of wine does affect the preferences of the panelists. In this case, clear wines are preferred while cloudy wines are considered to have not bad quality (Rais, 2011; Tika et al, 2016).

The FGD respondents also thought that the characteristics of the appearance of the pineapple wine samples, especially the clarity, had to be improved so that they could be well 
received by consumers. According to respondents, the yellow color of the pineapple wine samples really attracted attention and was one of the uniqueness of the pineapple wine samples. However, most people have a preference for a clear wine appearance as a marker of the high quality of a wine product. In addition, the clear yellow color is also synonymous with champagne products which are of a higher grade than wine. The appearance of the cloudy yellow pineapple wine sample is more synonymous with pineapple juice or juice.

The next AT parameter is the alcohol flavor parameter which gets an average value of $59.2 \%$. One possible reason for the low preference score for alcoholic flavors is that the aroma is covered in a "tape"-like aroma. The aroma is thought to have been detected through the retronasal olfactory when the panelists tasted and swallowed the sample so that it covered the flavor of the alcohol which should have been detected quite strongly. This was also supported by almost all of the panelists who stated that the aroma they first inhaled was the aroma of "tape". The significantly less detectable alcohol flavor resulted in a low preference score for the panelists against this parameter.

Even so, the pineapple wine samples have special characteristics that are rarely owned by other wines. According to the results of the FGD, the respondents were of the opinion that the relatively high alcohol content of the pineapple wine sample was not followed by a sharp flavor, so that all respondents thought the alcohol content they consumed was lower than it should be, which is only estimated at $4-6 \%$ even though it should be $9.5 \%$. The new heat effect appears about five minutes after tasting the sample.

The last parameter is the distinctive aroma of pineapple, which is detected through the orthonasal olfactory. The fruity, creamy aroma and distinctive aroma of pineapple caused by compounds such as ethyl acetate, methyl acetate, and methyl 3-methylthiopropionate are factors that play an important role in the assessment of preference for these parameters (Dellacassa et al, 2017; Qi et al, 2017). The score for this parameter is 53.1\%, which indicates that the panelists do not like the distinctive aroma caused by the pineapple wine sample. According to the panelists, their low score was based on the consideration that the aroma of pineapple, which should be one of the typical pineapple wine samples, was almost 
undetectable. As previously discussed, the pineapple wine sample underwent repeated heating to remove the bromelain enzyme and stop the yeast fermentation process, thereby evaporating the volatile compounds present. Meanwhile, volatile compounds are volatile compounds even though they are not at high temperatures so that they can cause aroma changes in alcoholic drinks such as wine (Longo et al, 2016; Toro et al, 2019).

FGD respondents also stated that pineapple wine sample has its most detectable flaws in its aroma parameter. With the high alcohol content, pineapple wine sample was expected to have a stronger alcohol flavor alongside with distinctive pineapple aroma. However, the alcohol and pineapple aroma of the pineapple wine sample were too soft and light that it was not showing any specific sensory characteristics other than the sweet taste. Just like AT panelists, FGD respondents also agreed that the aroma of pineapple wine samples resembled tape-like aroma. According to one respondent, if the pineapple aroma could be smelled more explicitly together with the alcohol flavor, wine could be paired with some of the high class food such as lightly smoked sauteed trout served with herbs like basil or thyme. The combination of sweetness level paired with the pineapple's tropical aroma will create a 'satisfying' effect when eaten with the smoky flavor and tenderness texture of fish. On the other hand, herbs addition was intended to enrich the combination flavors.

\section{CONCLUSIONS}

Generally, pineapple wine products are judged by its sweetness level, pineapple aroma, alcohol flavor, alcohol taste and its appearance. Pineapple wine samples have the advantage in sweetness level and alcohol flavor. Meanwhile, consumer's preference of a wine is a wine with a medium to low sweetness level, explicitly smelled distinctive aroma, high alcohol content (flavor and aroma) and clear to transparent color. Therefore, it could be concluded that FGD, QDA and AT conducted were effective in identifying sensory parameters of pineapple wine samples. 


\section{ACKNOWLEDGMENT}

This work is supported by the Microbiology Laboratory and Sensory Laboratory of Food Technology Department, Universitas Ciputra Surabaya.

\section{REFERENCES}

Allen, A. L., McGeary, J. E., \& Hayes, J. E. 2014. Polymorphisms in TRPV 1 and TAS 2Rs Associate with Sensations from Sampled Ethanol. Alcoholism: Clinical and Experimental Research 38(10): 2550-2560.

Barlagne, C., Cornet, D., Blazy, J-M., Diman, J-L., \& Ozier-Lafontaine, H. 2016. Consumers' Preferences for Fresh Yam: A Focus Group Study. Food Science \& Nutrition 5(1): 5466.

Belda, I., Ruiz, J., Esteban-Fernández, A., Navascués, E., Marquina, D., Santos, A., \& Moreno-Arribas, M. 2017. Microbial Contribution to Wine Aroma and Its Intended Use for Wine Quality Improvement. Molecules 22(2): 189.

Dellacassa, E., Trenchs, O., Fariña, L., Debernardis, F., Perez, G., Boido, E., \& Carrau, F. 2017. Pineapple (Ananas comosus L. Merr.) Wine Production in Angola: Characterisation of Volatile Aroma Compounds and Yeast Native Flora. International Journal of Food Microbiology 241: 161-167.

Farida, F. 2019. Analisis Biaya dan Nilai Tambah Pengolahan Wine Molase Tebu di Karang Asem Bali. Jurnal Riset Manajemen dan Bisnis (JRMB) Fakultas Ekonomi UNIAT 4(3): 339-348.

Freire, A. L., Ramos, C. L., \& Schwan, R. F. 2015. Microbiological and Chemical Parameters During Cassava Based-substrate Fermentation Using Potential Starter Cultures of Lactic Acid Bacteria and Yeast. Food Research International 76: 787-795.

Fu, D., Riordan, S., Kieran, S., Andrews, R. A., Ring, H. Z., \& Ring, B. Z. (2019). Complex Relationship Between Tas2 Receptor Variations, Bitterness Perception, and Alcohol Consumption Observed in A Population of Wine Consumers. Food \& Function 10(3): 1643-1652.

Gaffar, R., Lahming, L., \& Rais, M. 2018. Pengaruh Konsentrasi Gula terhadap Mutu Selai Kulit Jeruk Bali (Citrus maxima). Jurnal Pendidikan Teknologi Pertanian 3: 117-125.

Gaudette, N. J., \& Pickering, G. J. 2013. Modifying Bitterness in Functional Food Systems. Critical Reviews in Food Science and Nutrition 53(5): 464-481.

Guerrero, L. \& Xicola, J. 2018. "New Approach to Focus Group" dalam Ares, G \& Varela, P. (Ed.), Methods in Consumer Research, Vol. 1 (pp. 49-77). Amsterdam, Netherlands: Elsevier.

Harrington, R. J., \& Seo, H. S. 2015. The Impact of Liking of Wine and Food Items on Perceptions of Wine-food Pairing. Journal of Foodservice Business Research 18(5): 489-501.

Jackson, R.S. 2016. Wine Tasting: A Professional Handbook. Amsterdam: Academic Press.

Jiang, Y.C., Ma, L.N., Yuan, Y., Gong, X., \& Lin, L.L. 2018. Changes of Aroma Components of Pineapple Wine during Fermentation with Adt Strain. Materials Science and Engineering 392: 1-4.

Jordão, A. M., Vilela, A., \& Cosme, F. 2015. From Sugar of Grape to Alcohol of Wine: Sensorial Impact of Alcohol in Wine. Beverages 1(4): 292-310.

Kosseva, M.R., Joshi, V.K., \& Panesar, P.S. 2017. Science and Technology of Fruit Wine Production. Amsterdam, Netherlands: Elsevier.

Kurihara, K. 2015. Umami the Fifth Basic Taste: History of Studies on Receptor Mechanisms and Role as A Food Flavor. BioMed Research International. 
Ky, I., \& Teissedre, P. L. 2015. Characterisation of Mediterranean Grape Pomace Seed and Skin Extracts: Polyphenolic Content and Antioxidant Activity. Molecules 20(2): 21902207.

Li, H-H., Luo, L-Y., Wang, J., Fu, D-H., \& Zeng, L. 2019. Lexicon Development and Quantitative Descriptive Analysis of Hunan Fuzhuan Brick Tea Infusion. Food Research International 120: 275-284.

Longo, R., Blackman, J.W., Torley, P.J., Rogiers, S.Y., \& Schmidtke, L.M. 2016. Changes in Volatile Composition and Sensory Attributes of Wines During Alcohol Content Reduction. Journal of the Science of Food and Agriculture 97(1): 8-16.

Marangon, M., Vincenzi, S., \& Curioni, A. 2019. Wine Fining with Plant Proteins. Molecules 24(11): 2186.

Marques, W. L., Raghavendran, V., Stambuk, B. U., \& Gombert, A. K. 2016. Sucrose and Saccharomyces cerevisiae: A Relationship Most Sweet. FEMS Yeast research 16(1).

Maury, C., Sarni-Manchado, P., \& Cheynier, V. 2019. Highlighting Protein Fining Residues in A Model Red Wine. Food Chemistry 279: 272-278.

Mushter, J. 2018. VinoCalc - Gravity/Density/Sugar Conversions. VinoLab. Retrieved 22 December 2019 from http://www.vinolab.hr/calculator/gravity-density-sugarconversions -en19.

Mylona, A. E., Del Fresno, J. M., Palomero, F., Loira, I., Bañuelos, M. A., Morata, A., Benito, C. S., \& Suárez-Lepe, J. A. 2016. Use of Schizosaccharomyces Strains for Wine Fermentation-effect on The Wine Composition and Food Safety. International Journal of Food Microbiology 232: 63-72.

BSN. 2013. Anggur buah (SNI 4019: 2013). Jakarta: Badan Standarisasi Nasional.

Nasrun, N., Jalaluddin, J., \& Mahfuddhah, M. 2017. Pengaruh Jumlah Ragi dan Waktu Fermentasi terhadap Kadar Bioetanol yang Dihasilkan dari Fermentasi Kulit Pepaya. Jurnal Teknologi Kimia Unimal 4(2): 1-10.

Nanik, R. A. O. A. M. 2018. Karakteristik Minuman Beralkohol Dengan Variasi Kadar Ekstrak Buah Bit (Beta vulgaris L.) dan Lama Fermentasi. Jurnal Teknologi dan Industri Pangan 5(3).

Nurdalilah, O., Teoh, Y. P., Ooi, Z. X., \& Sam, S. T. 2018. Comparative Study on the Extraction of Bioactive Secondary Metabolites from Pomelo and Pineapple Peels Extract. IOP Conference Series: Materials Science and Engineering 429(1): 12040. IOP Publishing.

O'Sullivan, M.G. 2017. "Sensory Affective (Hedonic) Testing” dalam O'Sullivan, M.G., A Handbook for Sensory and Consumer-Driven New Product Development (pp. 39-57). Amsterdam, Netherlands: Elsevier.

Oktafa, H., Permadi, M. R., \& Agustianto, K. 2017. Studi Komparasi Data Uji Sensoris Makanan dengan Hedonic Test (Hedonik dan Mutu Hedonik), antara Algoritma Naïve Bayes Classifier dan Radial Basis Function Network. Prosiding.

Permadi, M. R., Oktafa, H., \& Agustianto, K. 2019. Perancangan Pengujian Hedonic Test, Uji Hedonik dan Mutu Hedonik Menggunakan Algoritma Radial Basis Function Network. Science and Information Technology Journal 2(2): 98-107.

Qi, N., Ma, L., Li, L., Gong, X., \& Ye, J. 2017. Production and Quality Evaluation of Pineapple Fruit Wine. IOP Conference Series: Earth and Environmental Science Vol. 100 No. 1, p. 012028.

Qi, N., Ma, L., Liu, X., Jiang, Y., Gong, X., \& Lin, L. 2017. Analysis of Aromatic Compositions of Pineapple Wines Fermented with Different Yeasts. Journal of Food Engineering and Technology 6(2): 95-100.

Rais, S. 2011. Persepsi Wisatawan Asing terhadap Produk Hatten Wine sebagai Seni Kuliner Bali untuk Daya Tarik Wisata. Doctoral Dissertation. Universitas Udayana Sadjuni. Denpasar.

Saputra, A. D. 2018. Perbandingan Kadar Alkohol dan Cita Rasa Wine Salak Pondoh (Salacca zalacca (Gaert.) Voss.) dengan Metode Red Wine, White Wine dan Sake Menggunakan Strain Yeast Polandia (Saccharomyces cereviseae). Universitas Sanata Dharma. Yogyakarta. 
Schoonenboom, J. \& Johnson, R.B. 2017. How to Construct A Mixed Methods Research Design. Köln Z Soziol 69(2): 107.

Soares, S., Brandão, E., Mateus, N., \& de Freitas, V. 2017. Sensorial Properties of Red Wine Polyphenols: Astringency and Bitterness. Critical Reviews in Food Science and Nutrition 57(5): 937-948.

Spence, C. 2016. The Crucial Role of Color in The Perception of Beverages. Beverage Impacts on Health and Nutrition: 305-316. Humana Press, Cham.

Stone, H., Bleibaum, R. N., \& Thomas, H. A. (2012). Sensory Evaluation Practices. Academic press.

Toro, N.d.T.d., Casas, F.F., Rial, J.A., Gonzáles, M.C.P., Sariol, H.C., Campa, J.N., Yperman, J., Vandamme, D., \& Carleer, R. 2019. Boltzmann-Based Empirical Model to Calculate Volume Loss during Spirit Ageing. Beverages 5(4): 60.

Vicsek, L. 2016. Improving Data Quality and Avoiding Pitfalls of Online Text-based Focus Groups: A Practical Guide. The Qualitative Report 21(7): 1232-1242.

Zhong, V. W., Kuang, A., Danning, R. D., Kraft, P., van Dam, R. M., Chasman, D. I., \& Cornelis, M. C. 2019. A Genome-wide Association Study of Bitter and Sweet Beverage Consumption. Human Molecular Genetics. 